\title{
The Analysis of Social Mobility
}

\author{
Volume I: Methods and Approaches
}

\section{Edited by KEITH HOPE}

A national survey of occupational change in a generation is the principal item in a programme of work on social mobility which is being undertaken by a group of Oxford sociologists. Preparatory work has involved pilot investigations directed, in particular, to problems of occupational classification. Relevant data collected under other auspices have been reanalysed. The results of this work will be reported in two volumes. The first includes papers on the grading of occupations, the quantification of intergenerational transmission of status, path analysis, canonical scoring of contingency and discussions of the relations between social mobility and marriage and fertility.

29 text-figures paper covers $£ 1.90$

OXFORD UNIVERSITY PRESS

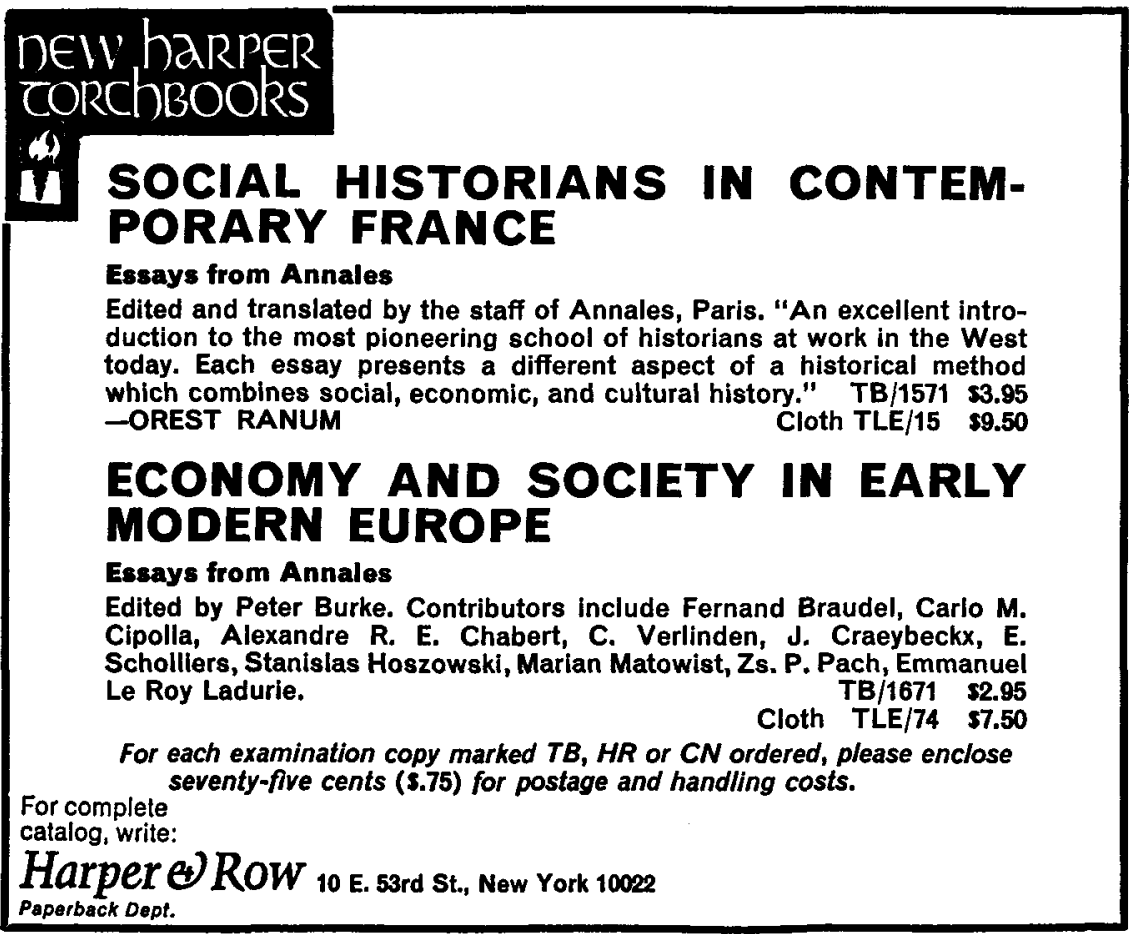




\section{ANNALES \\ Économies-Sociétés-Civilisations}

Revue bimestrielle, fondée en 1929 par Lucien FEBVRE et Marc BLOCH

Comité de Direction: Fernand BRAUDEL, Marc FERRO, Georges FRIEDMANN, Jacques LE GOFF, Emmanuel LE ROY LADURIE, Charles MORAZE

Secrétaire du Comité: Paul LEUILLIOT Secrétaire de la Rédaction: André BURGUIÈRE

27 ANNEE-No. 3

MAI-JUIN 1972

FRONTIËRES NOUVELLES

A. GUREVIC

La notion de propriété pendant le Haut Moyen Age

INTER-SCIENCES

G. LANTERI-LAURA

La chronicité dans la psychiatrie moderne française

OUTILLAGES

C. CASTELLANI

L. HENRY

Le rôle économique de la communauté juive de Carpentras au début du XVe siècle

Fécondité des mariages dans le quart sud-ouest de la France de 1720 à 1829 (I)

DÉBATS ET COMBATS
J. BAECHLER
De l'idéologie

LES DOMAINES DE L'HISTOIRE

V. RUTENBURG

R. PILLORGET

L. TILLY

J. P. POISSIN

COMPTES RENDUS
Révoltes ou révolutions en Europe aux XIVe et XVe siècles

Luttes de factions et intérêts économiques à Marseille de 1598 à 1618

La révolte frumentaire, forme de conflit politique en France

Le rôle socio-économique du notariat au XVIIIe siècle

Croyance et culture

Histoire de l'Histoire

Société, Economie et Politique au Moyen Age

Nations et Nationalités

Rédaction: 54, Boulevard Raspail, Paris-VIe (222-23-49)

Administration: Librairie Armand COLIN, ro3 Boulevard Saint Michel, Paris-Ve

Comptes Chèques Postaux: PARIS, $N^{\bullet} 2$ I 335-25

Abonnements 1971: France et Union Française : 43 F. Etranger: $60 \mathrm{~F}$.

Le numéro: $9 \mathrm{~F}$. Numéros spéciaux, $18 \mathrm{~F}$. 


\section{THE 'SHELBY CULLOM DAVIS CENTER FOR HISTORICAL STUDIES Popular Culture}

The Shelby Cullom Davis Center for Historical Studies announces that for the two years 1973-75 its Research Seminar will be devoted to the theme of Popular Culture. The Seminar will examine popular political values; popular religion and beliefs as expressed in symbolism, witchcraft, magic and astrology; popular organizations such as youth groups and secret societies; and popular activities such as festivals and games. The Center is particularly interested in the relation between popular and high culture as found, for example, in the interaction between oral and print traditions. In 1973-74, the main focus of the Seminar will be on popular religion and magical beliefs and their relationship to official religion, although research proposals in other areas of popular culture will also be considered. The Seminar hopes to attract scholars from other disciplines than history, and to gather together experts in different periods and countries.

The Center will offer a limited number of Research Fellowships for one or two semesters, designed primarily for highly recommended younger scholars with a year or more of teaching experience, although applications from senior scholars will also be considered.

Inquiries and fellowship application form requests should be addressed to the Executive Secretary, Davis Center for Historical Studies, 129 Dickinson Hall, Princeton University, Princeton, New Jersey 08540. The deadline for fellowship applications for the academic year 1973-74 is December 31, 1972.

THE WORLD TODAY

The monthly Journal of the Royal Institute of International Affairs provides the general reader with up-to-date and authoritative information on current world problems.

Recent issues have included the following articles:

NIXON'S CHINA PILGRIMAGE by Roderick MacFarquhar

THE ENLARGED COMMUNITY, THE US, AND OTHERS; A VIEW OF THE COMING NEGOTIATIONS by John Pinder

COMECON AND THE NEW MULTILATERALISM by Michael Kaser

THE INDIAN SUB-CONTINENT AFTER THE WAR by W. Klatt

Annual Subscription: $£ 3.25$ post free (USA and Canada $\$ 10$ ). 28p per copy.

Orders may be sent to booksellers and newsagents, or to the OXFORD UNIVERSITY PRESS, Press Road, Neasden, London, NW10 0DD (Tel. 01-450 8080). 


\section{The Journal of}
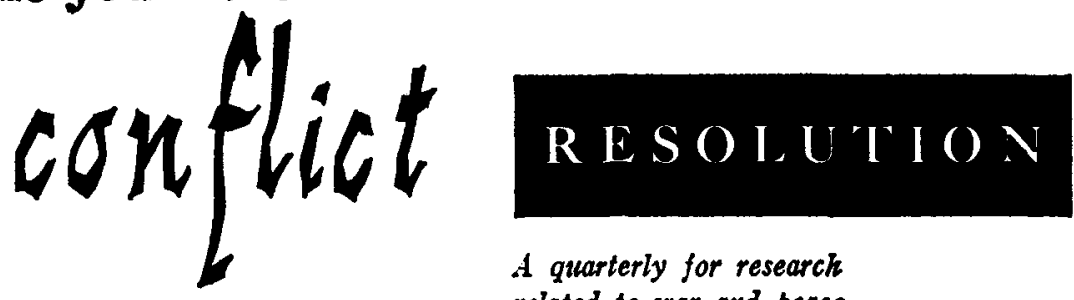

A quarterly for research

related to war and peace

Special Issue: June 1972 (Volume XVI, Number 2)

RESEARCH PERSPECTIVES ON THE ARAB-ISRAELI CONFLICT:

A SYMPOSIUM

Guest Editors: Joseph D. Ben-Dak and Edward E. Azar

With contributions by: Jonathon Wilkenfeld, Virginia Lee Lussier, and Dale Tahtinen; Barry M. Blechman; Randolf Siverson; Robert Burrowes and Douglas Muzzio; John E. Hofman; Alan Dowty; Saad lbrahim; Benjamin Beit-Hallahmi; and the editors.

$\$ 10.00$ per year for individuals, $\$ 18.00$ for institutions; single issues $\$ 3.00$

Published by The Journal of Conflict Resolution

The University of Michigan, Ann Arbor, Michigan 48104, U.S.A.

\section{Journal of Social Issues \\ Winter 1972 Volume XXVIII Number 2}

New Perspectives on Women

Issue Editors: Martha T. Mednick and Sandra S. Tangri

New Social Psychological Perspectives on Women ........................................... Understanding Women: Implications for Personality Theory and Research.........Rae Carlson The Changing Image of the Career Woman ................................Ravenna Helson The Invisible Woman: The Case of the Female Playwright in German $\mathrm{Literature...............}$
Sigrid Schoitz Novak Sex-Role Stereotypes: A Current Appraisal.......Inge K. Broverman, Susan Raymond Vogel, Donald M. Broverman, Frank E. Clarkson and Paul S. Rosenkrantz Sex-Role Attitudes and Psychological Well-Being............................Janice Porter Gump Sex-Role Attitudes in Finland, 1966-1970 ................................. Elina Haavio-Mannila Maternal Role Incompatibility and Fertility in Urban Latin America.........Paula H. Hass Early Childhood Experiences and Women's Achievement Motives...... Lois Wladis Hoffman Toward an Understanding of Achievement Related Conflicts in Women...... Matina S. Horner Determinants of Occupational Role Innovation Among College Women........................... Sandra Schwartz Tangri Conscious Factors Entering into Decisions of Women to Study Medicine.

Lillian Ka...................... Women as Politicians: The Social Background, Personality, and Political Careers of Female Party Leaders.................................. Edmond Costantini and Kenneth H. Craik The Emancipation of Man................................................................... Olaf Palme Biographical Sketches

Order from:

Journal of Social Issues

P.O. Box 1248

1972 ANNUAL SUASCRIPTION RATBS INSTITUTIONS $\$ 15.00$ INDIVIDUALS $\quad 9.00$ SINGLB COPIES

Published Quarterly by

THE SOCIETY FOR THE PSYCHOLOGICAL STUDY OF SOCIAL ISSUES

(a division of the American Psychological Association) 


\section{MINER V A}

A REVIEW OF SCIENCE, LEARNING AND POLICY

EDITED BY PROFESSOR EDWARD SHILS

VOL. $x$, NO. 3

JULY 1972

\section{COMMENT}

Stanford and Berlin: The Spheres of Politics and Intellect

ARTICLES

The Profession of Science and its Powers Joseph Ben-David

The Indian Academic Profession: The Origins of a Tradition of Subordination

Irene A. Gilbert

The Evaluation of Pollution: Balancing Gains and Losses Richard Stone

The Social Sciences in the Great Debate on Science Policy Andrew Shonfield

DISCUSSION

A Useful Institution of the Republic of Science

Alvin M. Weinberg

Temptations and Risks of the Scientific Adviser

R. V. Jones

\section{REPORTS AND DOCUMENTS}

Decision of the Advisory Board of Stanford University in the Matter of Professor H. Bruce Franklin, 5 January, 1972

CORRESPONDENCE

Harvey Brooks, Harry G. Johnson

BOOK REVIEWS

Arnold Thackray, G. Kloss, Kenneth Mellanby, K. M. Baker

Annual subscription: $£ 3.50 / \$ 10.50$

Single copy: $£ 1.00 / \$ 3.00$

Minerva, 59 St. Martin's Lane, London WC2N 4JS. 


\section{SURVEY}

\section{A Journal of East and West Studies}

Volume 18 No. 2 (83)

Spring 1972

\section{THE TRIAL OF VLADIMIR BUKOVSKY}

Samizdat

\section{Africa}

Ali A. Mazrui

P. J. Vatikiotis

Marxism

Mihajlo Mihajlov

Philip J. Jaffe

\section{Solzhenitsyn}

Michael Glenny

Per Egil Hegge

Annual subscription $£_{3}$ or US $\$ 8$

Student subscription $£_{1} \cdot 50$ or US $\$ 4$

Single copies: $75 \mathrm{p}$ or US $\$ 2$

Editorial office: Ilford House, ${ }_{1} 33$ Oxford Street, London WI R ITD

Subscription office: Oxford University Press, Press Road, Neasden,

London NW ro oDD 


\section{STUDI STORIGI}

SOMMARIO del n. $2-1972$

- Le Thanh Khoi

CONTRIBUTION A L'ÉTUDE DU MODE DE PRODUCTION ASIATIQUE: LE VIET NAM ANCIEN

- M. G. Rossi

MOVIMENTO CATTOLICO E CAPITALE FINANZIARIO: APPUNTI SULLA GENESI DEL BLOCCO CLERICO-MODERATO

- C. Pinzani

L'8 SETTEMBRE 1943: ELEMENTI ED IPOTESI PER UN GIUDIZIO STORICO

a. Soldani

IL 1830 IN EUROPA : DINAMICA E ARTICOLAZIONI DI UNA CRISI GENERALE PROBLEMI DI RICERCA

- V. Becagli

DAL TABLEAU ECONOMIQUE A L'AMI DES HOMMES. NOTE FISIOCRATICHE

NOTE CRITICHE

D. Bigalli

RECENTI PUBBLICAZIONI DI STORIA DELLE ERESIE

- S. Anselmi

VENEZIA E I BALCANI. LA SCALA * DI SPALATO TRA CINQUE E SEICENTO *

ข G. M. Bravo

LA PRIMA INTERNAZIONALE DOPO IL CONGRESSO DELL'AJA (1872)

c. Carbone

L'ANTICOLONIALISMO ITALIANO DURANTE LA PRIMA GUERRA D'AFRICA

CRONACHE

- C. Pazzagli

CREDITO, BANCHE E INVESTIMENTI ALLA SETTIMANA DI PRATO LIBRI RICEVUTI

Comitato direttivo: Giuliano Procacci, Ernesto Ragionieri,

Rosario Villari, Renato Zangheri

Direzione e redazione: Via Barberia $4^{2}, 40123$ Bologna 
Editor:

GEORGE A. KOURVETARIS

Northern Illinois Univ.

Associate Editors:

BENGT ABRAHAMSSON

Stockholm Univ., Sweden

PHILIP ABRAMS

Univ. of Durham, England

PANOS BARDIS

University of Toledo

FABRIZIO DE BENEDETTI

CESDI, Italy

HENRY BIENEN

Princeton University

A. BOPEGAMAGE

Gokhale Institute of Politics

Economics, India

MAJOR ROBERT CARROLL

U.S. Military Academy

MAN SINGH DAS

Northern Illinois Univ.

GINO GERMANI

Center for Advanced Study in

Behavioral Sciences

W. F. GUTTERIDGE

Univ. of Aston, England

HARRY HARRIS

Deputy Director of Equal

Opportunity, Office of

Asst. Sec. of Defense

SUZANNE KELLER

Princeton University

C. I. EUGENE KIM

Western Michigan Univ.

KEITH LEGG

University of Florida

SEYMOUR M. LIPSET

Harvard University

MOSHE LISSAK

Hebrew Univ., Israel

CHARLES MOSKOS, JR. Northwestern University

COLONEL ROGER NYE

U.S. Military Academy

NELSON W. POLSBY

Univ. of Calif., Berkeley

ARNOLD A. SIO

Colgate University

JAE SOUK SOHN

Seoul Nat'l Univ., Korea

RICHARD TOMASSON

Univ. of New Mexico

DIMITRIOS TSAKONAS

Panteios Supreme Schoo

of Polit. Science, Greece

ARTHUR VIDICH

New School for Social

Research

JERZY J. WIATR

Univ. of Warsaw, Poland

Assistant Editor:

BETTY DOBRATZ

\section{ANNOUNCING}

\section{Journal of Political and Military Sociology}

\section{An International and Interdisciplinary Biannual Publication}

JOURNAL OF POLITICAL AND MILITARY SOCIOLOGY welcomes articles of a theoretical, methodological, and empirical nature, book reviews, essay and review symposia, letters to the editor, comments and rejoinders, annotated bibliographies, news and announcements. A unique feature of the JPMS is to encourage the publication of scholarly articles dealing with the vital social, political, economic, and military issues.

The major objectives of the JPMS is to advance sociological knowledge in the neophytes of political and military sociology through the interdisciplinary and comparative approaches. The JPMS departs from the conventional academic orientation of professional social science publications by also encouraging contributors to address themselves to the vital issues of our time in the areas of political and military policy throughout the western and non-western world. A corollary objective of the JPMS is to foster and develop more genuine professional contacts and exchange of ideas and information concerning significant research and teaching developments in the fields of political and military sociology.

Manuscripts should be submitted in triplicate and in acceptable form to George A. Kourvetaris, Department of Sociology, Northern Illinois University, DeKalb, Illinois, 60115. Style, editorial procedures, and policies in preparing manuscripts will be provided upon request. The JPMS will be published in English biannually in Spring and Fall beginning in Spring, 1973. Subscription to the JPMS should also be sent to the aforementioned address.

\section{ORDER FORM}

Please enter my subscription to JOURNAL OF POLITICAL AND MILTARY SOCIOLOGY for the year(s)

$\$ 7.50$ (Individual/Institutional)

$\$ 6.50$ (Student)

NAME

ADDRESS

CITY STATE

COUNTRY

Cheque enclosed

Please bill me

Date: 


\title{
COMPARATIVE STUDIES IN SOCIETY AND HISTORY
}

\author{
An International Quarterly
}




\section{EDITORS}

Sylvia L. ThrupP

ERIC R. WOLF
Economic History

Anthropology
University of Michigan

University of Michigan

\section{EDITORIAL COMMITTEE}

$\begin{array}{lll}\text { ALBERT FEUERWERKER } & \text { East Asian History } & \text { University of Michigan } \\ \text { MOSES FINLEY } & \text { Ancient History } & \text { University of Cambridge } \\ \text { CHARLES GIBSON } & \text { Latin American History } & \text { University of Michigan } \\ \text { RAYMOND GREW } & \text { History } & \text { University of Michigan } \\ \text { EDWARD SHILS } & \text { Sociology } & \text { University of Cambridge and } \\ \text { Fniversity of Chicago }\end{array}$

\section{CONSULTING EDITORS}

\section{JACQUES BARZUN \\ REINHARD BENDIX \\ Peter Charanis \\ Carlo Cipolla}

Thomas Cochran BERNARD S. COHN

Karl Deutsch

S. N. EISENSTADT

George C. Homans

GeORGE Kubler

Claude Lévi-Strauss

JUAN LINZ

Arnaldo Momigliano

Lucian Pye

STEIN RoKKAN

Marshall Sahlins

Joseph J. SPENGLer

JOSEPH R. STRAYER

Philippe WolfF
History

Sociology

Byzantine Studies

Economic History

History

Anthropology and History

Government

Sociology

Sociology

Art History

Anthropology

Sociology

Political Science

Comparative Politics

Anthropology

Economics

History

History
Columbia University

University of California, Berkeley

Rutgers University

University of California, Berkeley and University of Pavia

University of Pennsylvania

University of Chicago

Harvard University

Hebrew University

Harvard University

Yale University

Collège de France

Yale University

University College, London

Massachusetts Institute of Technology

University of Bergen

University of Michigan

Duke University

Princeton University

University of Toulouse 


\title{
COMPARATIVE STUDIES IN \\ SOCIETYAND HISTORY
}

\section{AN INTERNATIONAL QUARTERLY}

\author{
VOLUME 141972
}

\section{CAMBRIDGE \\ AT THE UNIVERSITY PRESS}

1972 
Published by the Syndics of the Cambridge University Press Bentley House, P.O. Box 92, 200 Euston Road, London, N.W.1 American Branch: 32 East 57th Street, New York, N.Y. 10022

(C) Copyright 1972 by

the Society for the Comparative Study of Society and History

Requests for permission to quote or reproduce material in this journal should be sent to the London or New York offices

of Cambridge University Press 


\section{Contents}

William H. Alkire Concepts of Order in Southeast Asia and Micronesia

484-493

John A. Armstrong Old-Regime Governors: Bureaucratic and Patrimonial Attributes

RICHARD ASHCRAFT Marx and Weber on Liberalism as Bourgeois Ideology

DAVID BARKIN and JOHN W. BenNeTt Kibbutz and Colony: Collective Economies and the Outside World

AnTON BLOK The Peasant and the Brigand: Social Banditry Reconsidered

A. E. Campbell Open Diplomacy (Comment on Birn and Singer)

Carlo M. Cipolla The Diffusion of Innovations in Early Modern Europe

R. H. Dekmejian and M. J. Wyszomirski Charismatic Leadership in Islam: The Mahdi of the Sudan

Martha E. François Reformation and Society: An Analysis of Guy Swanson's Religion and Regime

MARC GALANTER The Aborted Restoration of 'Indigenous' Law in India

David Gutmann Comment: The Uses of Reminiscence

Edward Hansen, Peter Schneider and Jane SCHNEIDER Modernization and Development: The Role of Regional Elites and Noncorporate Groups in the European Mediterranean

IAN Henderson White Populism in Southern Rhodesia

Eric HoBsBawm Social Bandits: Reply (to Blok)

Daniel W. Howe The Decline of Calvinism: An Approach to its Study

S. C. Humphreys Review Article

R. S. KHARE Indigenous Culture and Lawyer's Law in India

ConRAD P. KotTAK Ecological Variables in the Origin and Evolution of African States: The Buganda Example

Leo KuPer Race, Class and Power: Some Comments on Revolutionary Change

T. M. McCASKIE Innovational Eclecticism: The Asante Empire and Europe in the Nineteenth Century

Charles Morrison Kinship in Professional Relations: A Study of North Indian District Lawyers

RHOADS MURPHeY City and Countryside as Ideological Issues: India and China 
Eul-Soo Pang and Ron L. Seckinger The Mandarins of Imperial Brazil

Beverley J. Pooley Comment on Khare

Alejandro Portes Rationality in the Slum: An Essay on Interpretive Sociology

RoberT M. SPAulding Japan's Search for Cultural Identity (Review Article)

$514-520$

Godfrey N. UzoIgWe Precolonial Markets in BunyoroKitara

Walter P. Zenner Aqiili Agha: The Strongman in the Ethnic Relations of the Ottoman Galilee 
Comparative Studies in Society and History is a forum for presentation and discussion of new research into problems of change and stability that recur in human societies through time or in the contemporary world. It sets up a working alliance between specialists in all branches of the social sciences and humanities. Debate and review articles bring the general reader in touch with current findings and issues.

\section{NOTES FOR CONTRIBUTORS}

Contributions may be descriptive, analytical or theoretical. Any article not in itself comparative may be accepted if it lends itself to comment that will place it in comparative perspective. Correspondence with the editors prior to the submission of articles will help to enable them to obtain such comment or a companion study. Emphasis in comparative studies may be either on similarities or, if these are significant enough and call for some recasting of generalisations, on differences. All contributions and editorial correspondence should be sent to the Editors, Comparative Studies in Society and History, Department of History, University of Michigan, Ann Arbor, Michigan 48104.

Two copies of each contribution, preferably accompanied by a stamped, addressed envelope, should be submitted. Both text and footnotes should be clearly typed with double spacing and wide margins; footnotes should appear on separate pages at the end of the article. Illustrations may be included by arrangement with the editors.

Contributors will receive 50 offprints bound in the journal covers. Any additional offprints must be ordered on receipt of the first proof.

\section{SUBSCRIPTIONS}

Comparative Studies in Society and History is published quarterly in January, March, June and September. Subscription per volume of four issues is $£ 5.00$ net in U.K., $\$ 14.00$ in U.S.A.; the price includes postage. Single issues sold for $£ 2.00$ net in U.K., $\$ 5.00$ in U.S.A., plus postage. Orders should be sent to a bookseller or subscription agent or direct to Cambridge University Press, Bentley House, 200 Euston Road, London NW1 2DB and in U.S.A. and Canada to Cambridge University Press, American Branch, 32 East 57th Street, New York, N.Y. 10022. Copies of the journal for subscribers in the United States of America are sent by air to New York to arrive with minimum delay. Second class postage paid at New York, N.Y. 
Comparative Studies in Society and History is a forum for presentation and discussion of new research into problems of change and stability that recur in human societies through time or in the contemporary world. It sets up a working alliance between specialists in all branches of the social sciences and humanities. Debate and review articles bring the general reader in touch with current findings and issues.

\section{NOTES FOR CONTRIBUTORS}

Contributions may be descriptive, analytical or theoretical. Any article not in itself comparative may be accepted if it lends itself to comment that will place it in comparative perspective. Correspondence with the editors prior to the submission of articles will help to enable them to obtain such comment or a companion study. Emphasis in comparative studies may be either on similarities or, if these are significant enough and call for some recasting of generalisations, on differences. All contributions and editorial correspondence should be sent to the Editors, Comparative Studies in Society and History, Department of History, University of Michigan, Ann Arbor, Michigan 48104.

Two copies of each contribution, preferably accompanied by a stamped, addressed envelope, should be submitted. Both text and footnotes should be clearly typed with double spacing and wide margins; footnotes should appear on separate pages at the end of the article. Illustrations may be included by arrangement with the editors.

Contributors will receive 50 offprints bound in the journal covers. Any additional offprints must be ordered on receipt of the first proof.

(C) Copyright 1972 by the Society for the Comparative Study of Society and History. Requests for permission to quote or reproduce material in this journal should be sent 


\section{COMPARATIVE STUDIES IN SOCIETY AND HISTORY}

Editorial Foreword

$385-386$

Race in Politics

IAn Henderson White Populism in Southern Rhodesia 387-399

Leo Kuper Race, Class and Power: Some Comments on Revolutionary Change

$400-421$

\section{Markets}

Godfrey N. Uzoigwe Precolonial Markets in BunyoroKitara

DaVID BARKIN and John W. BennetT Kibbutz and Colony: Collective Economies and the Outside World

\section{Conceptualization of Order}

William H. Alkire Concept of Order in Southeast Asia and Micronesia

\section{Debate}

AnTon BLoK The Peasant and the Brigand: Social Banditry Reconsidered 494-503

Eric Hobsbawm Social Bandits: Reply (to Blok) 503-505

A. E. Campbell Open Diplomacy (Comment on Birn and Singer)

Review Article

Robert M. Spaulding Japan's Search for Cultural Identity

(C) Society for the Comparative Study of Society and History, 1972

Cambridge University Press

Bentley House, 200 Euston Road, London NW1 2DB American Branch: 32 East 57th Street, New York, N.Y. 10022

$£ 2.00$ net in U.K.; $\$ 5.00$ in U.S.A.

Subscription price $£ 5.00$ net in U.K.; $\$ 14.00$ in U.S.A.

Printed in Great Britain by Alden \& Mowbray Ltd at the Alden Press, Oxford 